\title{
Synthesis of Crystalline Titanium(IV) Phosphates by Direct Precipitation from Ti(III) Solutions and Ion Exchange Properties of Some of the Prepared Phases
}

\author{
Per-Erik Tegehall \\ Department of Inorganic Chemistry, Chalmers University of Technology and University of Göteborg, \\ S-412 96 Göteborg, Sweden
}

\begin{abstract}
Tegehall, P.-E., 1986. Synthesis of Crystalline Titanium(IV) Phosphates by Direct Precipitation from Ti(III) Solutions and Ion Exchange Properties of Some of the Prepared Phases. - Acta Chem. Scand. A 40: 507-514.

Crystalline phases of titanium(IV) phosphate have been precipitated by oxidation of titanium(III) in phosphoric acid solutions. Three phases with layered structures have been prepared. Besides $\alpha$ - Ti $\left(\mathrm{HPO}_{4}\right)_{2} \cdot \mathrm{H}_{2} \mathrm{O}$ and $\gamma$ - $\mathrm{Ti}\left(\mathrm{HPO}_{4}\right)_{2} \cdot 2 \mathrm{H}_{2} \mathrm{O}$, known before, a new phase with chemical composition $\mathrm{Ti}_{4}\left(\mathrm{HPO}_{4}\right)_{7}\left(\mathrm{H}_{2} \mathrm{PO}_{4}\right)_{2} \cdot 0-4 \mathrm{H}_{2} \mathrm{O}$ has also been found.

The ion exchange properties of $\alpha-\mathrm{Ti}\left(\mathrm{HPO}_{4}\right)_{2} \cdot \mathrm{H}_{2} \mathrm{O}$ especially are very sensitive to the degree of crystallinity. Well crystallized $\alpha-\mathrm{Ti}\left(\mathrm{HPO}_{4}\right)_{2} \cdot \mathrm{H}_{2} \mathrm{O}$ can be prepared by oxidation of $\mathrm{Ti}(\mathrm{III})$ in $15 \mathrm{M} \mathrm{H}_{3} \mathrm{PO}_{4}$ at $140^{\circ} \mathrm{C}$.
\end{abstract}

Titanium(IV) phosphate is generally obtained as an amorphous product precipitated from solutions of phosphate and a titanium(IV) compound. Crystalline materials have been obtained by two different procedures. In 1967, Alberti $e t$ $a l .{ }^{1}$ showed that if the amorphous material is refluxed in phosphoric acid, a crystalline product is formed. However, to get a well crystallized product, refluxing times of over $350 \mathrm{~h}$ in $12 \mathrm{M} \mathrm{H}_{3} \mathrm{PO}_{4}$ were needed. ${ }^{2}$ According to the other method, ${ }^{3}$ the crystalline product is obtained directly by slow decomposition of titanium-fluoro complexes in the presence of phosphoric acid.

Two different crystalline phases of layered titanium phosphate have been characterized, $\alpha$ $\mathrm{Ti}\left(\mathrm{HPO}_{4}\right)_{2} \cdot \mathrm{H}_{2} \mathrm{O}(\alpha$-TiP $)$ and $\gamma-\mathrm{Ti}\left(\mathrm{HPO}_{4}\right)_{2} \cdot 2 \mathrm{H}_{2} \mathrm{O}$ $\left(\gamma\right.$-TiP) ${ }^{1,4}$ The precipitation conditions determine which of the phases is formed. High pressure, ${ }^{4}$ low temperature, low activity of titanium(IV), and high concentration of phosphoric acid favor the formation of the $\gamma$ phase. The crystal structure has not been completely determined for any of the titanium phosphate phases. However, the $\alpha$-titanium phosphate phase is isomorphic with $\alpha$ $\mathrm{Zr}\left(\mathrm{HPO}_{4}\right)_{2} \cdot \mathrm{H}_{2} \mathrm{O}$, which is monoclinic with space group $\mathrm{P} 2 / \mathrm{n} .^{6}$ The unit cell dimensions for $\alpha$-TiP are $a=8.631, b=5.002, c=16.176 \AA$, and $\beta=$ $110.20^{\circ}$. $^{7}$

Titanium phosphate is an inorganic ion exchanger with high resistance to temperature and radiation. ${ }^{8}$ The stability and ion exchange capability decrease with increased disorder in the structure. Therefore, it is of great interest to develop a simple method to precipitate well crystallized titanium phosphate. Both procedures described above have disadvantages. In the refluxing method, amorphous titanium phosphate has first to be prepared, then refluxed for a very long time. Precipitation from fluoro-complexed solutions is simple and fast, but the method is complicated by the high activity of hydrofluoric acid in the solution and the evaporation of hydrofluoric acid. This paper reports a new way to precipitate crystalline phases of titanium phosphate from Ti(III) solutions, and ion exchange properties of some of the prepared phases. In particular, the precipitation conditions and the properties of $\alpha$-Ti( $\left(\mathrm{HPO}_{4}\right)_{2} \cdot \mathrm{H}_{2} \mathrm{O}$ and a new titaniu$\mathrm{m}(\mathrm{IV})$ phosphate compound are discussed. 
Table 1. Precipitation conditions and titanium phosphates formed.

\begin{tabular}{rlll}
\hline $\mathrm{H}_{3} \mathrm{PO}_{4} / \mathrm{M}$ & $\begin{array}{l}\text { Oxidation } \\
\text { conditions }\end{array}$ & $\begin{array}{l}\text { Oxidation } \\
\text { time/h }\end{array}$ & Product \\
\hline 5 & Reflux $\left(102^{\circ} \mathrm{C}\right)$ & 35 & $\alpha$-TiP \\
10 & Reflux $\left(105^{\circ} \mathrm{C}\right)$ & 35 & $\alpha-\mathrm{TiP}$ \\
15 & Reflux $\left(155^{\circ} \mathrm{C}\right)$ & 20 & $\alpha-T i P$ \\
& & & $\gamma$-TiP \\
15 & In an oven & 50 & $\alpha-T i P$ \\
17 & Reflux $\left(185^{\circ} \mathrm{C}\right)$ & 15 & $\gamma-\operatorname{TiP}$ \\
17 & In an oven & 50 & $\delta$-TiP \\
\hline
\end{tabular}

\section{Experimental}

Preparation of Ti(III) solutions. One $\mathrm{g}$ titanium powder was dissolved in each of $5,10,15$ and $17 \mathrm{M} \mathrm{H}_{3} \mathrm{PO}_{4}\left(\mathrm{Ti} / \mathrm{PO}_{4} \approx 0.04\right)$ at $100-120^{\circ} \mathrm{C}$. Blue solutions of Ti(III) were obtained.

Precipitation of crystalline titanium phosphate. The phosphoric acid solutions of Ti(III) were heated in an oven at $140^{\circ} \mathrm{C}$ or were refluxed. Ti(III) was thus slowly oxidized to Ti(IV) by oxygen from the air and titanium(IV) phosphate precipitated. To compensate for evaporation during heating in the oven, water was added at intervals. When the solutions had completely lost their color, the precipitates were filtered off and washed with either distilled water or ethanol. The precipitations were performed in Pyrex glass equipment.

Analysis of the chemical composition. The $\mathrm{PO}_{4} / \mathrm{Ti}$ ratio was determined by the method used by Alberti et al. ${ }^{1}$ with some small changes. Since some of the phases did not dissolve in refluxing concentrated $\mathrm{H}_{2} \mathrm{SO}_{4}$, they were heated for $1 \mathrm{~h}$ at $90^{\circ} \mathrm{C}$ in $25 \mathrm{ml}$ of $1 \mathrm{M} \mathrm{KOH}$ before $25 \mathrm{ml}$ concentrated $\mathrm{H}_{2} \mathrm{SO}_{4}$ was added. They then dissolved directly without refluxing.

$X$-ray diffraction pattern. The X-ray powder patterns were taken for both wet and dry samples with $\mathrm{Ni}$-filtered $\mathrm{Cu} \mathrm{K} \alpha$ radiation.

Thermogravimetric analysis. The water and hydrogen content were determined by thermogravimetric measurements (TGA) at a heating rate of $4^{\circ} \mathrm{C} / \mathrm{min}$ to $200^{\circ} \mathrm{C}$ and thereafter at $10^{\circ} \mathrm{C} / \mathrm{min}$ to $800^{\circ} \mathrm{C}$.

Ion exchange titration curves. Samples of $0.100 \mathrm{~g}$ titanium phosphate were added to $50 \mathrm{ml} 0.10 \mathrm{M}$ $\mathrm{MCl}\left(\mathrm{M}=\mathrm{Li}^{+}, \mathrm{Na}^{+}, \mathrm{K}^{+}\right)$, then different amounts of 0.10 M MOH were added in drops, under stirring, and so slowly that the $\mathrm{pH}$ never exceeded 8 to avoid hydrolysis. The mixtures were thoroughly shaken at times and the $\mathrm{pH}$ of the solutions was measured at regular intervals.

\section{Results}

Precipitates from oxidation of Ti(III) solutions. The precipitates formed from the different Ti(III) solutions are presented in Table 1 . The precipitated phases obtained from refluxing phosphoric acid were those expected: $\boldsymbol{\gamma}$-TiP from very concentrated solutions of phosphoric acid $(>15 \mathrm{M})$ and $\alpha$-TiP from less concentrated solutions $(<15 \mathrm{M})$. In $15 \mathrm{M} \mathrm{H}_{3} \mathrm{PO}_{4}$, both $\alpha$-TiP and $\gamma$-TiP were formed. However, when prepared in an oven, only $\alpha$-TiP was formed from $15 \mathrm{M}$ $\mathrm{H}_{3} \mathrm{PO}_{4}$, and a new phase, $\delta$-TiP, was formed from $17 \mathrm{M} \mathrm{H}_{3} \mathrm{PO}_{4}$.

The glass equipment was very slightly etched by the solutions of $17 \mathrm{M}$ phosphoric acid. However, no elements other than phosphorous and titanium could be detected in the precipitated phases by energy dispersive X-ray analysis (EDAX), so it probably had no effect on the result.

The X-ray powder patterns, the chemical composition and the density of the different phases are shown in Tables 2 and 3. The values for $\alpha$-TiP are from the oven precipitated phase. The $\mathrm{X}$-ray diffraction curves of $\alpha$-TiP precipitated by refluxing showed that it had a lower degree of crystallinity.

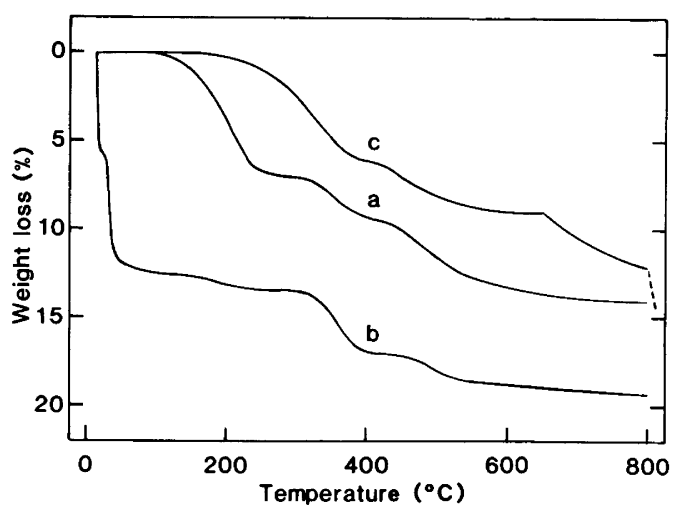

Fig. 1. TGA curves for (a) $\alpha-\mathrm{Ti}\left(\mathrm{HPO}_{4}\right)_{2} \cdot \mathrm{H}_{2} \mathrm{O}$, (b) $\gamma$ $\mathrm{Ti}\left(\mathrm{HPO}_{4}\right)_{2} \cdot 2 \mathrm{H}_{2} \mathrm{O}$ and (c) $\delta-\mathrm{Ti}_{4}\left(\mathrm{HPO}_{4}\right)_{7}\left(\mathrm{H}_{2} \mathrm{PO}_{4}\right)_{2}$. $\sim 3 \mathrm{H}_{2} \mathrm{O}$. --- weight loss after reaching $800^{\circ} \mathrm{C}$. 
Table 2. X-ray diffraction patterns of the crystalline titanium phosphates.

\begin{tabular}{|c|c|c|c|c|c|c|c|}
\hline \multicolumn{2}{|l|}{$\alpha-\mathrm{TiP}$} & \multicolumn{2}{|l|}{$\gamma$-TiP } & \multicolumn{4}{|l|}{$\delta$-TiP } \\
\hline$d(\AA)$ & $I / I_{o}$ & $d(\AA)$ & $I / I_{0}$ & $d(\AA)$ & $\mathrm{I} / \mathrm{o}$ & $d(\AA)$ & $I / I_{0}$ \\
\hline 7.54 & 63 & 11.40 & 100 & 6.81 & 93 & 2.46 & 7 \\
\hline $4.25^{a}$ & 18 & $5.56^{a}$ & 9 & 5.51 & 32 & 2.44 & 3 \\
\hline 4.04 & 10 & 4.29 & 13 & 4.38 & 59 & 2.40 & 15 \\
\hline 3.45 & 100 & 3.85 & 3 & 4.31 & 30 & 2.28 & 2 \\
\hline 3.42 & 54 & 3.56 & 1 & 4.26 & 18 & 2.26 & 20 \\
\hline 3.14 & 4 & 3.45 & 39 & 4.04 & 14 & 2.22 & 8 \\
\hline 3.02 & 1 & 3.29 & 3 & 3.75 & 99 & 2.19 & 5 \\
\hline 2.88 & 1 & 3.17 & 5 & 3.71 & 100 & 2.17 & 5 \\
\hline 2.61 & 6 & 3.06 & 4 & 3.56 & 36 & 2.13 & 2 \\
\hline 2.58 & 3 & 3.03 & 9 & 3.42 & 24 & 2.10 & 3 \\
\hline 2.53 & 11 & 2.79 & 6 & 3.33 & 48 & 2.08 & 7 \\
\hline 2.49 & 24 & 2.59 & 2 & 3.29 & 43 & 2.04 & 2 \\
\hline 2.46 & 3 & 2.55 & 5 & 3.18 & 12 & 2.02 & 3 \\
\hline 2.39 & 3 & 2.45 & 1 & 3.14 & 9 & 1.94 & 3 \\
\hline 2.37 & 4 & 2.34 & 1 & 3.09 & 32 & 1.91 & 4 \\
\hline 2.28 & 1 & $2.31^{a}$ & 6 & 2.98 & 7 & 1.88 & 5 \\
\hline 2.24 & 7 & 2.17 & 2 & 2.89 & 2 & 1.86 & 7 \\
\hline 2.23 & 3 & 2.15 & 2 & 2.84 & 24 & 1.84 & 16 \\
\hline 2.16 & 2 & 2.09 & 1 & 2.83 & 5 & & \\
\hline 2.09 & 1 & 2.08 & 2 & 2.76 & 16 & & \\
\hline 2.02 & 5 & 2.04 & 1 & 2.65 & 14 & & \\
\hline 1.96 & 4 & 1.99 & 1 & 2.63 & 5 & & \\
\hline 1.94 & 3 & 1.95 & 2 & 2.58 & 6 & & \\
\hline 1.88 & 2 & 1.93 & 4 & 2.55 & 5 & & \\
\hline \multirow{2}{*}{1.87} & 6 & 1.84 & 5 & 2.53 & 31 & & \\
\hline & & 1.73 & 3 & 2.48 & 8 & & \\
\hline
\end{tabular}

${ }^{a}$ Doublets.

The Peak at $d=3.42 \AA$ was missing, the intensities of the other peaks were lower and the peaks were broader. The $\mathrm{PO}_{4} / \mathrm{Ti}$ ratio was very nearly 2 for both $\alpha$ - and $\gamma$-TiP and 2.25 for the new phase, $\delta$-TiP.

TGA curves. Fig. 1 shows the TGA curves for $\alpha$-, $\gamma$ - and $\delta$-TiP prepared from 15 and $17 \mathrm{M} \mathrm{H}_{3} \mathrm{PO}_{4}$. For the $\gamma$ phase, the result was mainly the same as reported earlier. ${ }^{9-11}$ The condensation of $\mathrm{HPO}_{4}$ groups was achieved in two steps for both the $\alpha$ and the $\gamma$ phase. This has not been observed for the $\alpha$ phase before, ${ }^{1,10,12-14}$ and was only so for oven-prepared $\alpha$-TiP.

Since the $\mathrm{PO}_{4} / \mathrm{Ti}$ ratio for the $\delta$ phase was 2.25 , the weight loss due to condensation of phosphate groups is about $9 \%$, if the water content is not too high. The observed total weight loss was 10 $14 \%$. The low value was obtained from a sample precipitated from a solution with very low activ- ity of water. The X-ray diffraction patterns were exactly the same for all the $\delta$ phases, indicating that the water content varies without changes in the structure. The weight loss at $250-300^{\circ} \mathrm{C}$ was followed by a decomposition of the structure, so the water could not be removed without destroying the structure. $\operatorname{TiP}_{2} \mathrm{O}_{7}$ and probably an amorphous phase were formed.

Stability of the $\delta$-titanium phosphate phase. $\delta$-TiP was not stable when stored in water for a long time. The solid became amorphous and the density decreased. The $\delta$ phases with low water content were more stable than the phases with higher water content.

Ion exchange of $\alpha-\mathrm{Ti}\left(\mathrm{HPO}_{4}\right)_{2} \cdot \mathrm{H}_{2} \mathrm{O}$. Titration with $\mathrm{LiOH}, \mathrm{NaOH}$ and $\mathrm{KOH}$ of $\alpha$-TiP precipitated from 5 and $10 \mathrm{M} \mathrm{H}_{3} \mathrm{PO}_{4}$ gave the same result as reported before. ${ }^{2,12}$ Somewhat different results were achieved for $\alpha$-TiP formed from $15 \mathrm{M}$ 
Table 3. Chemical composition and density of the crystalline titanium phosphates.

\begin{tabular}{lccc}
\hline Compound & $\alpha$-TiP & $\gamma$-TiP & $\delta$-TiP \\
\hline $\mathrm{Ti}($ mmoles $/ \mathrm{g})$ & 3.83 & 3.64 & 3.70 \\
$\mathrm{PO}_{4} / \mathrm{Ti}($ mole ratio) & 2.01 & 2.05 & 2.25 \\
Weight loss at $800^{\circ} \mathrm{C}(\%)$ & 14.1 & 19.3 & $10-14$ \\
Estimated formula & $\mathrm{Ti}\left(\mathrm{HPO}_{4}\right)_{2} \cdot \mathrm{H}_{2} \mathrm{O}$ & $\mathrm{Ti}\left(\mathrm{HPO}_{4}\right)_{2} \cdot 2 \mathrm{H}_{2} \mathrm{O}$ & $\mathrm{Ti}_{4} \mathrm{H}_{11}\left(\mathrm{PO}_{4}\right)_{9} \cdot 0-4 \mathrm{H}_{2} \mathrm{O}$ \\
Interlayer distance $(\AA)$ & 7.54 & 11.40 & 6.81 \\
Density $\left(\mathrm{g} / \mathrm{cm}^{3}\right)$ & 2.58 & 2.41 & 2.51 \\
$n($ moles Ti/cm & 7.5 & 10.0 & 6.3 \\
\hline
\end{tabular}

$\mathrm{H}_{3} \mathrm{PO}_{4}$ and especially for $\alpha$-TiP prepared by oxidation in the oven. Therefore, the results from titration of $\alpha$-TiP are from an oven-prepared sample, if not otherwise specified. The obtained ionexchanged phases are presented in Table 4.

Titration with $\mathrm{LiOH}$ (i). The titration curve of $\alpha$ TiP with LiOH is shown in Fig. 2. The lithium ions are exchanged in one step, but the $\mathrm{pH}$ plateau is not developed until after $10 \%$ exchange and ends after $90 \%$ exchange. The corresponding X-ray diffraction patterns changed only between 10 and $90 \%$ conversion. That is, at $0-10 \%$ exchange, the solid solution $\mathrm{Ti}\left(\mathrm{H}_{1+\mathrm{x}} \mathrm{Li}_{\mathrm{x}}\right)_{2}\left(\mathrm{PO}_{4}\right)_{2}$ $\mathrm{H}_{2} \mathrm{O}$ exists, where $0<\mathrm{x}<0.1$. Thereafter, a nearly fully converted lithium phase is formed up to $90 \%$ conversion. At $90 \%$ exchange, another solid solution, $\mathrm{To}\left(\mathrm{H}_{\mathrm{x}}, \mathrm{Li}_{1-\mathrm{x}}\right)_{2}\left(\mathrm{PO}_{4}\right)_{2} \cdot \mathrm{H}_{2} \mathrm{O}$ appears, where $0<\mathrm{x}<0.1$.

The X-ray diffraction pattern of the lithium-exchanged phase (Table 5) showed a new peak at $d$ $=7.8 \AA$, but the peak at $\mathrm{d}=7.5 \AA$ was still there; so the new peak is not caused by changes in the interlayer distance. Except for the new peak, the X-ray pattern is exactly the same as reported before ${ }^{12}$ and as those achieved for $\alpha$-TiP precipitated from 5 and $10 \mathrm{M} \mathrm{H}_{3} \mathrm{PO}_{4}$. Since the lithium phase is very similar to the original one, the solid solution of lithium can indeed be expected.

Titration with $\mathrm{NaOH}$ (ii). The titration curves of $\alpha$-TiP with $\mathrm{NaOH}$ showed great differences among the different precipitated $\alpha$ phases. For $\alpha$ TiP of low crystallinity, a titration curve at $25^{\circ} \mathrm{C}$ (Fig. 3a) with the same odd appearance as described by Alberti et al. was obtained. ${ }^{2}$ These authors showed that at $25^{\circ} \mathrm{C}$, the ion exchange process is a mixture of two independent processes, one that dominates at temperatures below $20^{\circ} \mathrm{C}$ and one that dominates at temperatures

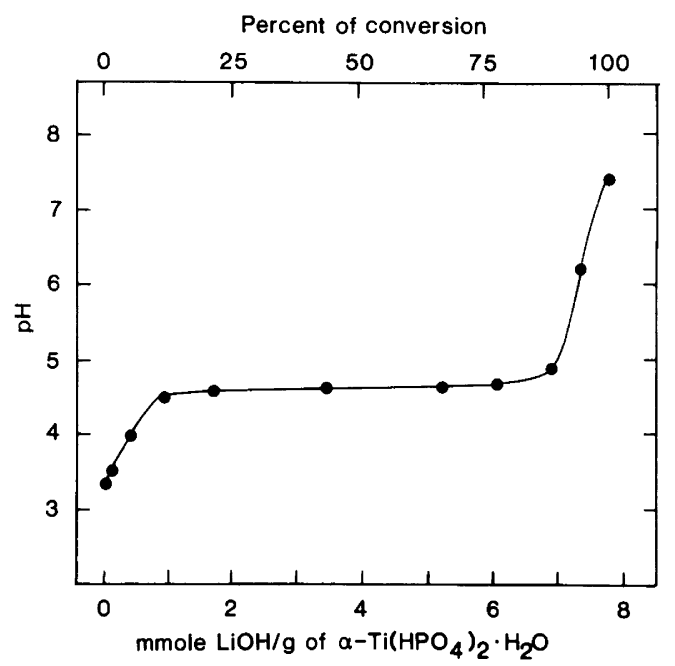

Fig. 2. Titration curve of oven-precipitated $\alpha$ $\mathrm{Ti}\left(\mathrm{HPO}_{4}\right)_{2} \cdot \mathrm{H}_{2} \mathrm{O}$ with $0.10 \mathrm{M} \mathrm{LiOH}$ at $25^{\circ} \mathrm{C}$. pH measured after $24 \mathrm{~h}$.

above $40^{\circ} \mathrm{C}$. At low temperature, $\alpha$-TiHNa $\left(\mathrm{PO}_{4}\right)_{2} \cdot 4 \mathrm{H}_{2} \mathrm{O}$ and $\alpha-\mathrm{Ti}\left(\mathrm{NaPO}_{4}\right)_{2} \cdot 3 \mathrm{H}_{2} \mathrm{O}$ are formed; at the higher temperatures, $\alpha-\mathrm{TiHNa}$ $\left(\mathrm{PO}_{4}\right)_{2} \cdot \mathrm{H}_{2} \mathrm{O}$ and $\alpha-\mathrm{Ti}\left(\mathrm{NaPO}_{4}\right)_{2} \cdot \mathrm{H}_{2} \mathrm{O}$ are formed.

Table 4. Interlayer distances in obtained ion-exchanged phases of $\alpha-\mathrm{Ti}\left(\mathrm{HPO}_{4}\right)_{2} \cdot \mathrm{H}_{2} \mathrm{O}$.

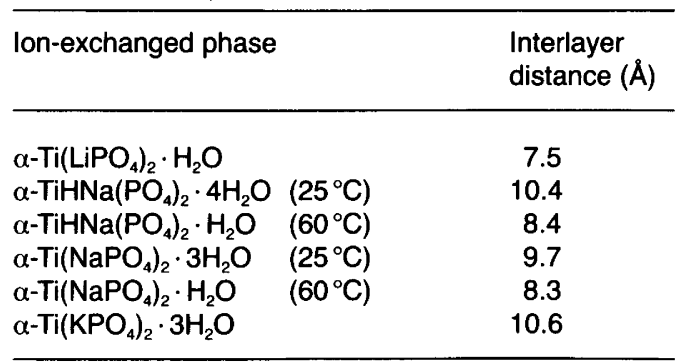




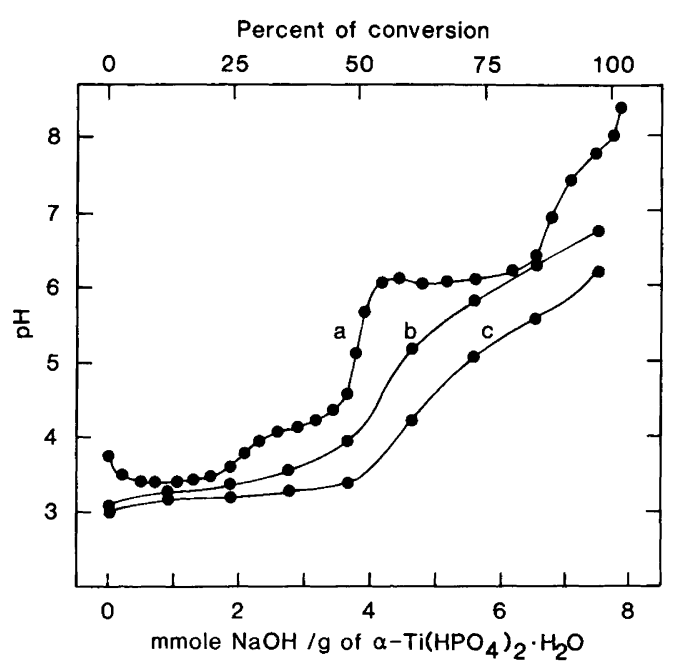

Fig. 3. Titration curves with $\mathrm{NaOH}$ (a) at $25^{\circ} \mathrm{C}$ with $\alpha$ TiP precipitated in refluxing $10 \mathrm{M} \mathrm{H}_{3} \mathrm{PO}_{4}$, (b) $25^{\circ} \mathrm{C}$ with oven-precipitated $\alpha-\mathrm{TiP}$ and (c) at $60^{\circ} \mathrm{C}$ with oven-precipitated $\alpha$-TiP. $\mathrm{pH}$ measured at $25^{\circ} \mathrm{C}$ and after $24 \mathrm{~h}$.

Fig. 3 shows the titration curves with $\mathrm{NaOH}$ at 25 and $60^{\circ} \mathrm{C}$ of $\alpha$-TiP precipitated in an oven. Between themselves, the curves are very similar, except that the ion exchange at the higher temperature happens at a somewhat lower $\mathrm{pH}$. However, the curve at $25^{\circ} \mathrm{C}$ is quite different from that reported before. The X-ray diffraction pattern showed that at $25^{\circ} \mathrm{C}$, only $\alpha$-TiHNa $\left(\mathrm{PO}_{4}\right)_{2}$.

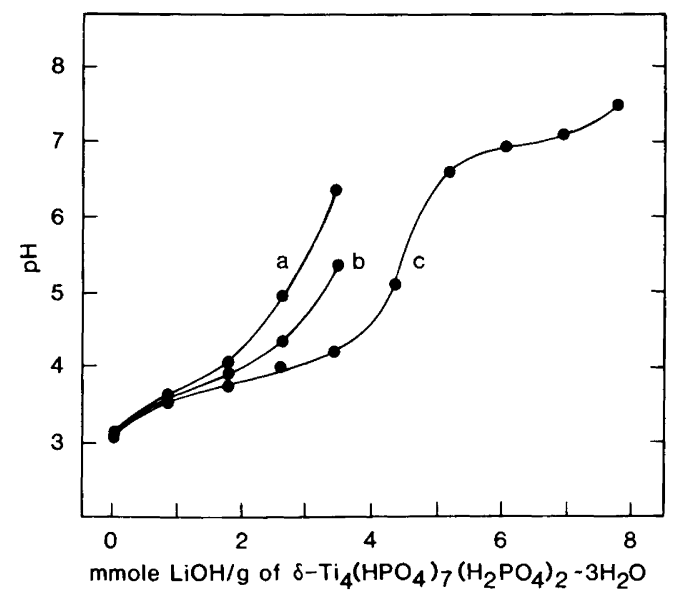

Fig. 4. Titration curves of $\delta$-TiP with $\mathrm{LiOH}$ at $25^{\circ} \mathrm{C}$. $\mathrm{pH}$ measured after (a) $24 \mathrm{~h}$, (b) $48 \mathrm{~h}$ and (c) $168 \mathrm{~h}$.

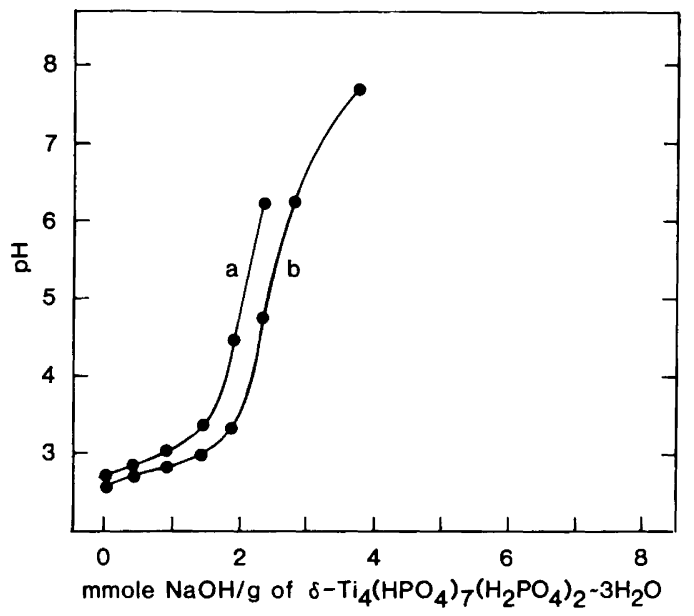

Fig. 5. Titration curves of $\delta$-TiP with $\mathrm{NaOH}$ at $25^{\circ} \mathrm{C}$. $\mathrm{pH}$ measured after (a) $24 \mathrm{~h}$ and (b) $168 \mathrm{~h}$.

$4 \mathrm{H}_{2} \mathrm{O}$ was formed up to $50 \%$ conversion and at $60^{\circ} \mathrm{C}$ only $\alpha$-TiHNa $\left(\mathrm{PO}_{4}\right)_{2} \cdot \mathrm{H}_{2} \mathrm{O}$ was formed. At both temperatures, fully exchanged phases were formed at $50-100 \%$ conversion, but the lack of well defined plateaus indicates that there also exist solid solutions. The fully exchanged forms were at $25^{\circ} \mathrm{C} \alpha-\mathrm{Ti}\left(\mathrm{NaPO}_{4}\right)_{2} \cdot 3 \mathrm{H}_{2} \mathrm{O}$, and at $60^{\circ} \mathrm{C}$ $\alpha-\mathrm{Ti}\left(\mathrm{NaPO}_{4}\right)_{2} \cdot \mathrm{H}_{2} \mathrm{O}$ with a layer distance of 9.7 and $8.3 \AA$, respectively. The $\mathrm{X}$-ray diffraction patterns of the half and fully exchanged forms are shown in Table 5.

Titration with $\mathrm{KOH}$ (iii). $\alpha$-TiP exchanges potassium at $\mathrm{pH} \sim 6.5$, but is simultaneously hydrolyzed and becomes amorphous. However, ionexchanged products could be prepared. If the oven-prepared $\alpha$-TiP was mixed for a short period with $1 \mathrm{M} \mathrm{K}_{2} \mathrm{HPO}_{4}$, a weak peak at $d=$ $10.6 \AA$ was observed in the X-ray diffraction pattern. The product was, however, hydrolyzed in less than $10 \mathrm{~min}$. A little more stable against hydrolysis was the $\alpha$-TiP precipitated from refluxing $15 \mathrm{M} \mathrm{H}_{3} \mathrm{PO}_{4}$. When it was exchanged with potassium in $1 \mathrm{M} \mathrm{K}_{2} \mathrm{HPO}_{4}$, a weak peak at $8.9 \AA$ and a strong peak at $10.6 \AA$ were observed in the $\mathrm{X}$-ray diffraction pattern. The products were hydrolyzed when washed with water, and were not analyzed. But the strong peak at $10.6 \AA$ is probably from the fully exchanged phase, $\mathrm{Ti}\left(\mathrm{KPO}_{4}\right)_{2} \cdot 3 \mathrm{H}_{2} \mathrm{O} .{ }^{15}$

Ion exchange of $\delta$-TiP. The rate of ion exchange of $\delta$-TiP with lithium and sodium was fast for the 
first 1-2 mmole/g exchanged ions, but then slowed down considerably. The theoretical ion exchange capacity is $9.7-10.4 \mathrm{mmole} / \mathrm{g}$, but was not obtained with either lithium or sodium.

Titration with $\mathrm{LiOH}$ (i). The titration curve of $\delta$ TiP with $\mathrm{LiOH}$ (Fig. 4) shows that lithium is exchanged in two steps. The X-ray diffraction pattern (Table 6) shows that two well defined phases are formed; all three phases are however very similar.

Titration with $\mathrm{NaOH}$ (ii). If $0.100 \mathrm{~g}$ of $\delta-\mathrm{Ti}_{4}$ $\left(\mathrm{HPO}_{4}\right)_{7}\left(\mathrm{H}_{2} \mathrm{PO}_{4}\right)_{2} \cdot 3 \mathrm{H}_{2} \mathrm{O}$ is added to $50 \mathrm{ml}$ $0.10 \mathrm{M} \mathrm{NaCl}$, the $\mathrm{pH}$ of the solution drops to 2.5 (Fig. 5). That means that one of the protons on each of the dihydrogen phosphate groups is exchanged before the titration starts. At the same time, the X-ray diffraction pattern is changed (Table 6). When titrated with $\mathrm{NaOH}$, two more hydrogen ions per formula could be exchanged, but without any more changes in the X-ray pattern. The addition of more than $3.5 \mathrm{mmole} / \mathrm{g}$ of $\mathrm{NaOH}$ resulted in hydrolysis.

Titration with $\mathrm{KOH}$ (iii). When titrated with $\mathrm{KOH}, \delta$-TiP was hydrolyzed at a $\mathrm{pH}$ of 7 . No changes in the $\mathrm{X}$-ray diffraction pattern were observed.

\section{Discussion}

Structure of the new $\delta$-TiP phase. When ion exchanged with lithium and sodium, the X-ray diffraction pattern of the new $\delta$-TiP phase is only slightly changed. The most important change is that the peak at $d=6.81 \AA$ is moved to a higher $d$ value when ion exchanged with lithium and to a lower $d$ value when exchanged with sodium. Therefore, it is probable that $\delta$-TiP also has a layered structure, with an interlayer distance of $6.81 \AA$.

The water content was not affected by the ion exchange, either with lithium or sodium ions. The increase in the $\mathrm{d}$ value with $\mathrm{Li}^{+}$and decrease with $\mathrm{Na}^{+}$are in contrast with the ionic dimensions of these ions. A possible explanation of this is that they occupy different sites in the structure.

The chemical analysis showed that the $\mathrm{PO}_{4} / \mathrm{Ti}$ ratio was 2.25 for $\delta$-TiP. That is, the chemical formula ought to contain either $\mathrm{H}_{2} \mathrm{PO}_{4}$ groups or intercalated $\mathrm{H}_{3} \mathrm{PO}_{4}$. Intercalated $\mathrm{H}_{3} \mathrm{PO}_{4}$ has been found in $\gamma$-TiP $;{ }^{11}$ but it was easily removed by washing with water and the $\mathrm{X}$-ray diffraction pattern was very similar to that for anhydrous $\gamma$-TiP. The $\delta$-TiP phase could not be transformed by washing with water either to the $\alpha$ phase or the $\gamma$

Table 5. X-ray diffraction patterns of lithium- and sodium-exchanged phases of $\alpha$-TiP.

\begin{tabular}{|c|c|c|c|c|c|c|c|c|c|}
\hline \multicolumn{2}{|c|}{$\mathrm{Ti}\left(\mathrm{LiPO}_{4}\right)_{2} \cdot \mathrm{H}_{2} \mathrm{O}$} & \multicolumn{2}{|c|}{$\mathrm{TiHNa}\left(\mathrm{PO}_{4}\right)_{2} \cdot \mathrm{H}_{2} \mathrm{O}$} & \multicolumn{2}{|c|}{$\mathrm{TiHNa}\left(\mathrm{PO}_{4}\right)_{2} \cdot 4 \mathrm{H}_{2} \mathrm{O}$} & \multicolumn{2}{|c|}{$\mathrm{Ti}\left(\mathrm{NaPO}_{4}\right)_{2} \cdot \mathrm{H}_{2} \mathrm{O}$} & \multicolumn{2}{|c|}{$\mathrm{Ti}\left(\mathrm{NaPO}_{4}\right)_{2} \cdot 3 \mathrm{H}_{2} \mathrm{O}$} \\
\hline$d(\AA)$ & $1 / I_{0}$ & $d(\AA \AA)$ & $1 / I_{0}$ & $d(\AA)$ & $1 / I_{0}$ & $d(\AA)$ & $I / I_{\mathrm{o}}$ & $d(\AA)$ & $1 / I_{0}$ \\
\hline 7.80 & 55 & 8.42 & 100 & 10.40 & 100 & 8.25 & 100 & 9.72 & 100 \\
\hline 7.54 & 90 & 4.16 & 25 & 3.92 & 30 & 4.41 & 10 & 4.34 & 5 \\
\hline 4.38 & 10 & 3.66 & 20 & 3.31 & 40 & 4.19 & 70 & 4.18 & 8 \\
\hline 4.28 & 10 & 3.45 & 35 & & & 4.03 & 10 & 4.02 & 20 \\
\hline 4.20 & 20 & 3.38 & 55 & & & 3.65 & 55 & 3.83 & 15 \\
\hline 3.99 & 5 & 2.94 & 40 & & & 3.50 & 90 & 3.60 & 10 \\
\hline 3.50 & 55 & 2.65 & 5 & & & 3.25 & 10 & 3.50 & 10 \\
\hline 3.42 & 100 & 2.56 & 20 & & & 2.85 & 10 & 3.30 & 35 \\
\hline 3.15 & 5 & & & & & 2.81 & 20 & 3.14 & 10 \\
\hline 2.69 & 10 & & & & & 2.72 & 20 & 2.81 & 10 \\
\hline 2.59 & 10 & & & & & 2.54 & 90 & 2.57 & 20 \\
\hline 2.55 & 15 & & & & & 2.47 & 35 & & \\
\hline 2.52 & 10 & & & & & & & & \\
\hline 2.48 & 5 & & & & & & & & \\
\hline 2.43 & 5 & & & & & & & & \\
\hline 2.41 & 10 & & & & & & & & \\
\hline 2.36 & 5 & & & & & & & & \\
\hline 2.27 & 15 & & & & & & & & \\
\hline
\end{tabular}


TITANIUM(IV) PHOSPHATES

Table 6. X-ray diffraction patterns of lithium and sodium ion-exchanged phases of $\delta$-titanium phosphate.

\begin{tabular}{|c|c|c|c|c|c|}
\hline \multicolumn{2}{|c|}{$\delta-\mathrm{TiP}+4 \mathrm{mmol} \mathrm{\textrm {Li } ^ { + } / \mathrm { g }}$} & \multicolumn{2}{|c|}{$\delta-\mathrm{TiP}+8 \mathrm{mmol} \mathrm{\textrm {Li } ^ { + } / \mathrm { g }}$} & \multicolumn{2}{|c|}{$\delta-\mathrm{TiP}+4 \mathrm{mmol} \mathrm{Na}^{+} / \mathrm{g}$} \\
\hline$d(\AA)$ & $1 / I_{0}$ & $d(\AA)$ & $1 / I_{0}$ & $d(\AA)$ & $I / I_{0}$ \\
\hline 6.87 & 56 & 7.04 & 57 & 6.64 & 48 \\
\hline 5.55 & 18 & 5.51 & 20 & 4.37 & 18 \\
\hline 4.35 & 31 & 4.34 & 11 & 4.30 & 7 \\
\hline 4.26 & 18 & 4.28 & 18 & 4.02 & 10 \\
\hline 3.73 & 100 & 4.19 & 20 & 3.70 & 100 \\
\hline 3.52 & 26 & 3.72 & 100 & 3.58 & 35 \\
\hline 3.45 & 10 & 3.53 & 17 & 3.30 & 17 \\
\hline 3.41 & 7 & 3.44 & 18 & 3.18 & 4 \\
\hline 3.30 & 24 & 3.27 & 13 & 3.03 & 6 \\
\hline 3.10 & 12 & 3.14 & 19 & 2.78 & 27 \\
\hline 2.85 & 28 & 2.89 & 20 & 2.72 & 15 \\
\hline 2.76 & 10 & 2.87 & 11 & 2.58 & 2 \\
\hline 2.64 & 9 & 2.76 & 11 & 2.52 & 13 \\
\hline 2.53 & 16 & 2.26 & 11 & 2.46 & 2 \\
\hline 2.42 & 4 & 2.52 & 19 & 2.40 & 12 \\
\hline \multirow[t]{3}{*}{2.37} & 3 & 2.48 & 6 & & \\
\hline & & 2.42 & 7 & & \\
\hline & & 2.36 & 9 & & \\
\hline
\end{tabular}

phase and the X-ray diffraction pattern is completely different. Therefore, it is more likely that it contains $\mathrm{H}_{2} \mathrm{PO}_{4}$ groups rather than intercalated $\mathrm{H}_{3} \mathrm{PO}_{4}$. If the $\mathrm{PO}_{4} / \mathrm{Ti}$ ratio of 2.25 is assumed to be correct, then the formula can be written as $\mathrm{Ti}_{4}\left(\mathrm{HPO}_{4}\right)_{7}\left(\mathrm{H}_{2} \mathrm{PO}_{4}\right)_{2} \cdot \mathrm{xH}_{2} \mathrm{O}$, where $0<\mathrm{x}<4$. A zirconium phosphate with a $\mathrm{PO}_{4} / \mathrm{Zr}$ ratio of 2.2 has been prepared in molten phosphoric acid. ${ }^{16}$ Its X-ray diffraction pattern was not published, but it was different from other zirconium phosphates. It may have the same structure as $\delta$-TiP.

The yield for both $\alpha$ - and $\gamma$-TiP, when precipitated by the reflux method, was nearly $100 \%$. The yield for $\alpha$-TiP and $\delta$-TiP, when oven-precipitated was much less: about $50 \%$. Thus, the solution is very supersaturated and the activity of $\mathrm{Ti}(\mathrm{IV})$ very high when titanium phosphate is precipitated in an oven. That can explain why $\gamma$-TiP is not formed in the oven, since it is precipitated at low activity of Ti(IV). ${ }^{5}$

In the refluxing method, amorphous titanium phosphate is formed in the condenser. Some of it is washed down in the solution and can there act as crystallization nuclei. Therefore, the precipitation of titanium starts at a low activity of $\mathrm{Ti}(\mathrm{IV})$ and due to rigorous stirring, supersaturation is prevented.
To exclude the possibility that $\mathrm{Ti}(\mathrm{III})$ influences the formation of $\delta$-TiP, a solution of Ti(III) in $17 \mathrm{M} \mathrm{H}_{3} \mathrm{PO}_{4}$ was allowed to oxidize completely at room temperature. When the clear solution was heated in an oven at $120^{\circ} \mathrm{C}, \delta$-TiP was precipitated.

Ion exchange properties of $\alpha$-TiP. The $\alpha$-TiP phases precipitated from the different solutions have quite different ion exchange properties. The reason is probably that they have various degrees of crystallinity. $\alpha$-TiP precipitated by oxidation in an oven can be expected to have the highest degree of crystallinity since it is slowly precipitated from a highly concentrated solution with a high activity of Ti(IV).

With oven-precipitated $\alpha$-TiP, only TiHNa $\left(\mathrm{PO}_{4}\right)_{2} \cdot 4 \mathrm{H}_{2} \mathrm{O}$ is formed up to $50 \%$ exchange, and the ion exchange is performed at a low $\mathrm{pH}$ and at a high rate. In contrast, for $\alpha$-TiP precipitated from phosphoric acid with low concentrations, both $\mathrm{TiHNa}\left(\mathrm{PO}_{4}\right)_{2} \cdot 4 \mathrm{H}_{2} \mathrm{O}$ and $\mathrm{TiHNa}\left(\mathrm{PO}_{4}\right)_{2} \cdot \mathrm{H}_{2} \mathrm{O}$ are formed. The ion exchange starts at a considerably higher $\mathrm{pH}$ and the ion exchange rate is slow. It can be noticed that the $\mathrm{pH}$ of ion exchange drops after some sodium has been exchanged for $\alpha$-TiP of low crystallinity. A possible explanation is that there are stronger 
bonds between the layers in the less crystalline products. The diffusion of sodium ions in the structure will then be aggravated and the formation of highly hydrated products with large interlayer distances inhibited.

When an $\alpha$-TiP sample precipitated in an oven was titrated with $\mathrm{NaOH}$, hydrolysis started before it was completely converted to the disodium form. The hydrolysis was more severe at $25^{\circ} \mathrm{C}$ than at $60^{\circ} \mathrm{C}$. At $25^{\circ} \mathrm{C}$, the interlayer distance of the fully converted form is $9.7 \AA$ and at $60^{\circ} \mathrm{C}$, $8.3 \AA$. But the ionic radii of the exchanged cation also has a great influence on the stability of the exchanged phase. This is very obvious for potassium, with which no exchanged form can be prepared without rapid hydrolysis. In the ionexchanged products of $\alpha$-TiP with large interlayer distance, the attractive forces between the layers are weak. Hence they are easily separated and hydrolyzed.

Ion exchange properties of $\delta$-TiP. The interlayer distance in $\delta$-TiP is very short $(6.81 \AA)$ and only lithium and sodium could be exchanged. However, despite the short distance, the rate of ion exchange of the first exchanged ions was very high and performed at a low pH. No ion-exchanged forms of $\delta$-TiP with interlayer distance larger than $7.0 \AA$ were formed. Thus, the structure seems to be stable only when the interlayer distance is very small.

Stability of crystalline titanium phosphate. In Table 3 , the number, $n$, of titanium ions contained per $\mathrm{cm}^{2}$ of a layer is calculated. The $n$ value is highest for $\gamma$-TiP and lowest for $\delta$-TiP, as is the stability of the different structures.

\section{Conclusions}

Oxidation of Ti(III) in concentrated phosphoric acid solutions is a very useful method for precipitating well crystallized phases of titanium(IV) phosphate. By decreasing the rate of oxidation, the degree of crystallinity and the particle size can be increased. The ion exchange properties depend on the degree of crystallinity, especially for $\alpha$-TiP. Unfortunately, the stability against hydrolysis during ion exchange decreases with increasing degree of crystallinity. It is also decreased by large cations such as potassium.

Acknowledgement. My thanks are due to Professor Nils-Gösta Vannerberg for valuable discussions.

\section{References}

1. Alberti, G., Cardini-Galli, P., Costantino, U. and Torraca, E. J. Inorg. Nucl. Chem. 29 (1967) 571.

2. Alberti, G., Costantino, U. and Giovagnotti, M. L. L. Gazz. Chim. Ital. 110 (1980) 61.

3. Alberti, G. and Torracca, E. J. Inorg. Nucl. Chem. 30 (1968) 317.

4. Alluli, S., Ferragina, C., La Ginestra, A., Massucci, M. A. and Tomassini, N. J. Inorg. Nucl. Chem. 39 (1977) 1043.

5. Alberti, G., Costantino, U. and Luciani Giovagnotti, M. L. J. Inorg. Nucl. Chem. 41 (1979) 643.

6. Troup, J. M. and Clearfield, A. Inorg. Chem. 16 (1977) 3311 .

7. Clearfield, A., Nancollas, G. H. and Blessing, R. H. In: Marinsky, J. A. and Marcus, Y., Eds., Ion Exchange and Solvent Extraction, Marcel Dekker, New York 1973, Vol. 5, Chapter 1.

8. Alberti, G. Acc. Chem. Res. 11 (1978) 163.

9. La Ginestra, A. and Massucci, M. A. Thermochim. Acta 32 (1979) 241.

10. Costantino, U. and La Ginestra, A. Thermochim. Acta 58 (1982) 179.

11. Llavona, R., Garcia, J. R., Suárez, M. and Rodriguez, J. Thermochim. Acta 86 (1985) 281.

12. Takaguchi, K. and Tomita, I. J. Chromatogr. 118 (1976) 263.

13. Clearfield, A. and Frianeza, T. N. J. Inorg. Nucl. Chem. 40 (1978) 1925.

14. Kobayashi, E. Bull. Chem. Soc. Jpn. 48 (1975) 3114.

15. Garcia, J. R., Suarez, M., Llavona, R. and Rodriguez, J. J. Chem. Soc., Dalton Trans. (1984) 2605.

16. Torracca, E., Alberti, G., Platania, R., Scala, P. and Galli, P. Soc. Chem. Ind. (London) (1970) 315.

Received March 3, 1986. 